\title{
Baglyas Ferenc
}

\section{Musttisztítás hatása a bor érzékszervi minőségére}

\author{
Ferenc Baglyas \\ The Effect of Must Clarification on the Quality of Wine
}

\begin{abstract}
Összefoglalás
A musttisztítás alapvető célja a must fizikai, fiziko-kémiai és biológiai állapotának optimalizálása $a z$ erjedés irányítósához és a borminőség javításához. Technológiai és minőségi szempontok (lassabb erjedés, tisztább illat, elsődleges és erjedési aromaanyagok jobb megörzése) alapján ma a must minél hatékonyabb tisztítását célozzák meg a minöségi fehérbor készítésben. A must normál körülmények között $k b$. 10-30\% szedimentet tartalmaz és ez az arány rothadt szölö és eröteljes préselés esetén csak növekedhet. A különbözö kezelésekkel mennyiségét $10 \%$ de, inkább 5\% alá kell csökkenteni. A szediment tartalom jelentös részének eltávolításával a must belső felülete lecsökken, megkönnyítve ezzel a must további kezelését. A tisztítás után visszamaradó anyagok a borélesztök számára nélkülözhetetlen tápanyagokat tartalmaznak, ezért fontos, hogy túltisztítással ne csökkentsük mennyiségüket az optimális szint alá. Kiemelendö még, hogy jelentös illat- és aroma anyagok károsodhatnak a flotációs, a hiperoxidációs, és a szeparációs musttisztításoknál, ezért ezek nem kerültek alkalmazásra.

Kulcsszavak: must tisztítása, illat, aroma, bor összbenyomás
\end{abstract}

\section{Summary}

The main goal of must clarification is to optimize the physical-chemical and biological conditions of must in order to be able to better manage fermentation and improve wine quality. Must clarification has to be as effective as possible is on the basis of technological and quality aspects (slower fermentation, cleaner fragrance, better conservation of primary and fermentation aromas) in the preparation of quality white wine. Must usually contains 10-30\% sediment and this ratio can be higher when rotten grapes are processed or when the pressure in the press is high. Different clarification treatments can lower this rate below 5-10\%. By removing sediment the inner surface of must is reduced and further must/wine treatments become easier. It is important not to overclarify the must because sediment contains nutriment for yeasts. As must flotation, separation and hyper-oxidation can damage fragrances and aromas, these methods were not applied.

Keywords: must clarification methods, fragrances, aromas, overall wine qualiy

\section{BEVEZETÉS}

A hagyományos, kisüzemi borászatokban évszázadokon keresztül alacsony nyomáson, kézi préssel préselték ki a zúzott cefrét (gyakran kocsánnyal együtt). A kíméletes préselés, kis nyomás következtében az elválasztott must lebegőanyag tartalma alacsony volt. Az erjesztés pincehőmérsékleten, kis űrtartalmú edényekben (leginkább fahordókban) történt. Ennek eredményeképpen az erjedés viszonylag lassan ment végbe és megőrződtek az elsődleges és erjedési zamatanyagok, illatok. 
A nagyüzemi borászkodással iparszerűen, nagy tömegben dolgozzák fel a szőlőt. A feldolgozás, préselés során jelentős mennyiségú lebegó anyag kerül a mustba és a borba. Ez stabilitási problémát okoz, az erjedési hőmérsékletet emeli és az illat, aroma anyagok eltúnnek a borból vagy átalakulnak. Ezért ma már bevált gyakorlat a fehérborok készítésekor, hogy a mustot erjesztés előtt tisztítják.

A tisztításnak többféle módszere létezik:

- ülepítés (gravitációs úton)

- nyálkázás (rothadt szőlő feldolgozásakor)

- kénessavas ülepítés hútéssel egybekötve

- derítőszerek alkalmazása (agyagásvány, fehérje alapú)

- derítőszerrel történő erjesztés

- flotálás

- szeparálás

- hiperoxidáció

Ezek költséges beavatkozások, melyekkel vékonyítjuk a mustot, kivonunk belőle értékes aromaanyagokat és az élesztők számára fontos tápanyagokat.

Ebben a cikkben mikrovinifikációs körülmények között Cserszegi fűszeres szőlőfajta mustján végeztem musttisztítást, mustderítést és hasonlítottam össze a kezeletlen bor minőségével.

\section{IRODALMI ÁTTEKINTÉS}

A musttisztítás alapvető célja a must fizikai, fiziko-kémiai és biológiai állapotának optimalizálása az erjedés irányításához és a borminőség javításához. Technológiai és minőségi szempontok (lassabb erjedés, tisztább illat, elsődleges és erjedési aromaanyagok jobb megőrzése) alapján ma a must minél hatékonyabb tisztítását célozzák meg a minőségi fehérbor készítésben (EPERJESI, 1998, 2000).

A must normál körülmények között kb. 10-30\% szedimentet tartalmaz és ez az arány rothadt szőlő és erőteljes préselés esetén csak növekedhet. A különböző kezelésekkel mennyiségét $10 \%$ de, inkább $5 \%$ alá kell csökkenteni. A szediment tartalom jelentős részének eltávolításával a must belső felülete lecsökken, megkönnyítve ezzel a must további kezelését. A tisztítás után visszamaradó anyagok a borélesztők számára nélkülözhetetlen tápanyagokat tartalmaznak, ezért fontos, hogy túltisztítással ne csökkentsük mennyiségüket az optimális szint alá. Kiemelendő még, hogy jelentős illat- és aroma anyagok károsodhatnak a flotációs, a hiperoxidációs, és a szeparációs musttisztításoknál.

A hiperoxidációs eljárás tekintetében, a szőlőfajtákra gyakorolt hatása nem egységes, az általam vizsgált Cserszegi fúszeres fajtánál a szakirodalom a negatív hatásokat emeli ki (EPERJESI, 2000).

Mindezek következtében, a most felsorolt eljárásokat nem vettem alkalmazásba, mint musttisztítási lehetőséget, helyette a kíméletesebbeket helyeztem előtérbe, illetve vizsgáltam a kísérletek során.

\section{Gravitációs ülepítés}

Szerényebb mértékű tisztulást eredményező eljárás, amelynél az ülepedés a gravitációs erőnek köszönhető. Az ülepítési idő meghosszabbításával a letisztult must mennyisége növelhető. Célszerű a módszert hútéssel kombinálni, a must lehútése $10^{\circ} \mathrm{C}$ alatti hőmérsékletre, fékezi az erjedés beindulását. $\mathrm{A}$ gravitációs ülepítésnek technológiai feltételei vannak, melyek között elsődleges a must erjedésmentessége. A must szabadkénessavtartalma (15-25 $\mathrm{mg} / \mathrm{l})$ biztosítja üzemi körülmények között a 24-48 órás erjedésmentességet. A must zavarosító anyagai közül csak azok ülepíthetők, amelyek a folyadéknál nagyobb sűrǔségúek. A folyadékkal azonos, vagy ettől kisebb súrúségú anyagok, semmilyen ülepítő hatásra nem ülepszenek le. Azok a mustok, amelyek sok kis fajsúlyú üledékanyagot tartalmaznak, ülepítéssel nem tisztíthatók elég hatékonyan. Ülepítés után a tisztult mustot lefejtjük üledékéről (EPERJESI, 1998, 2000). 
II. Bentonitos derítés

A bentonit a borászatban termolabilis fehérjék megkötésére és ezáltal, a későbbi fehérjezavarosodások megakadályozására használjam. Derítő hatása abban áll, hogy a musthoz adva néhány perc alatt durva pehelyképződést okoz, majd a finom részecskék a bentonit pelyheken adszorbeálódnak. A keletkezett zavarosító anyagok flokkulálnak, kicsapódnak és leülepszenek. A bentonit igény nagyon eltérő lehet fajtától, termőhelytől is függ. Csapadékban szegény évek, föleg a nyár végi, őszi időszakban, magasabb bentonit igényt eredményeznek. A szőlő a bogyókban energiatárolóként fehérjét raktároz. Minél nagyobb stressznek van kitéve a növény, annál több tartalékot képez. Ezzel magyarázható a csapadékszegény évjáratokban a magasabb bentonitigény. Alacsonyabb hőmérsékleten a bentonitigény és a derítés ideje is megnő. A derítési múvelet különösen ajánlható a Botrytises szőlő mustjánál, mivel a bentonit megköti a lakkáz fehérje komponenseit, ezzel az enzim múködésképtelenné válik, így meggátolja a barnatörés kialakulását. Bentonitos derítés után a mustok extrakt-, invertcukor-, hamu-, hamualkalitás-, borkősav- és almasav tartalmában mérhető változás nem történik (FERENCZI, 1979).

A bentonit túlzott mértékű használatával a mustba kerülő bizonyos anyagok, elsősorban a kalcium, kedvezőtlen hatást gyakorolnak az állóképességre.

A túlzott mértékű fém beoldódás számos kiválás előidézője, melyek esetenként igen nehezen szüntethetők meg (FERENCZI, 1979).

A manapság alkalmazott korszerü bentonitokat szigorú tisztítási eljárásnak vetik alá, amellyel már kiküszöbölhető a fent nevezett probléma. A bentonitos kezelés a mustok értékes aminosavainak $20 \%-40 \%$-át is kivonhatja.

A fehérjéken kívül jelentős mennyiségú alacsonyabb molekulasúlyú nitrogén vegyületet (peptonok, polipeptidek) is eltávolít. A bentonit fehérjemegkötő képessége akkor nagyobb, ha a must savasabb és a cserzőanyag tartalom kevesebb. A fehér mustok bentonitos kezelés után világosabbá, zöldesebb árnyalatúvá válnak, mert részben adszorbeálja a mély színt okozó polifenolokat. A növényvédőszer maradványok eltávolításában a bentonit két értékes tulajdonsága vesz részt: a kation cserélő képessége és derítő hatása.

A bentonitok duzzadási képessége az egyik legfontosabb tulajdonsága, minél nagyobb, annál hatékonyabb az adszorbeáló képessége, mivel nagyobb aktív felülettel rendelkeznek. A túlzott duzzadás a növekvő bentonit térfogattal szemben viszont nagyobb termékveszteséget eredményez (JANKY, 1997).

\section{Zselatinos derítés:}

A zselatin a legelterjedtebb fehérjetartalmú derítőszer a borászatban. Pozitív elektromos töltésének köszönhetően a must negatív töltésú tannintartalmával képez csapadékot. A keletkezett pelyhes csapadék a felületén adszorbeálja a szuszpendált részecskéket. A zselatin flokkulációját elősegítik a kationok, az oxigén, az alacsonyabb hőmérséklet és a magasabb pH érték. A fémek (kationok) közül elsősorban az igen aktív háromértékű vassal reagál, tannin-vas komplex formában flokkulálva a zselatinnal. Használatával csökkenthető a nem kívánt polifenolok (pl. a keserú ízt okozó katechinek) mennyisége. Meggátolja a barnulást és a nem tipikus öregedést is (EPERJESI, 1998, 2000).

\section{ANYAG ÉS MÓDSZER}

Ugyanazt a megfelelően egalizált mustot különböző módszerekkel tisztítottam. Az ezt megelőző és az ezt követő eljárások ugyanakkor, minden minta esetében ugyanazok voltak. Ennek megfelelően lehetőség nyílt a különböző eljárással tisztított mustokból erjesztett borok összehasonlító vizsgálatára érzékszervi szempontból.

\section{A vizsgált fajta}

A Cserszegi füszere a harmadik leginkább elterjedt fehér borszőlőfajtánk. Az összes szőlőtermesztő ország közül - különösen a filoxéravész óta - Magyarországon terjedt el a legjobban borvidékeink legmegbízhatóbb, kiváló minőséget adó fajtája. 
Meleg fekvést igényel, talaj iránt kevésbé igényes, kevésbé rothadékony fajta. Szeptember elején érik, a beérése ötéves átlagban 20,4 mustfokot mutat. Bőven termő, termésátlaga 12-14 t/ha. Bora muskotályos illatú, zamatos, tüzes, savasabb karakterú. (CSEPREGI-ZILAI, 1988)

A Cserszegi fúszeres a Kunsági borvidék egyik legjelentősebb fajtája is egyben. Választásunk azért esett erre a fajtára, mert kiválóan alkalmazkodik az eltérő borászati technológiákhoz és így, általánosabb érvényú következtetéseket tudok levonni a kísérletek eredményeiből.

Ampelográfiai leírás

SZÁRMAZÁSA: Irsai Olivér x Piros tramini, Bakonyi K., Magyarország

\section{AMPELOGRÁFIAI JELLEMZŐI:}

Tőkéje középerős vagy gyenge, a hajtások bókolóak, viszonylag kevés hónaljhajtást képeznek. Vesszői világosbarnák, hosszú ízközűek. Vitorlája brozoszöld, csupasz, fényes. Levelei az Irsai Olivérhez hasolóak, de sötétebb árnyalatúak.

Fürtje középnagy, vállas, kúpos, fürtátlagtömege $150 \mathrm{~g}$.

Bogyói, gömbölyúek, 2 g körüli tömegűek, húspiros színúek, vékony, szívós héjúak, lédúsak, élénk savtartalmúak.

TERMESZTÉSI ÉRTÉKE: Korán fakad és érik. Mustja szeptember elején eléri a 17-18 mustfokot. A környezettel szemben igényes, a szárazságra érzékeny fajta. Terhelésre érzékeny fajták közé tartozik, kevés másodtermést nevel. Bora illatos, sajátosan füszeres zamatú, élénk savtartalmú, cukormentes extrakttartalma kiemelkedő.

\section{ELLENÁLLÓKÉPESSÉGE:}

Viszonylagos fagytűrése kiemelkedő, rothadásellenállósága is figyelemre méltó. Peronoszpórára, lisztharmatra közepesen érzékeny.

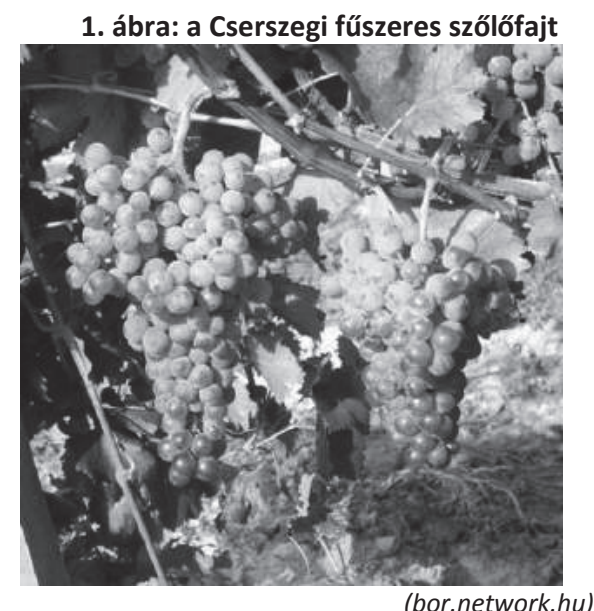

A kísérlet módszere

Az Cserszegi fúszeres szüretelésének időpontja: 2015. 09. 05.

A kora reggeli szüretet követően a beszállított szőlőt zúztam. A színmustot azonnal elválasztottam, mert a fenolanyagok egy része a héjból oldódik be. A szikkadt cefrét kosaras préssel kipréseltem és külön tettem. A színmustot 12 órán át ülepítettem, majd zselatint adtam hozzá. Az így kezelt musthoz élesztő tápsót és fajélesztőt adtam. Az erjesztés üvegballonban történt $15-20{ }^{\circ} \mathrm{C}$ hőmérsékleten. $A z$ erjedés befejeződése után 4 héttel az újbort lefejtettem, majd 2 héttel később bentonit alapú derítőanyaggal lederítettem. Az így letisztított új borok (kezelt és kontrol) érzékszervi bírálatra kerültek.

\section{Ülepítéses musttisztítás}

A színmust és a présmust szabad kénessav tartalmát $100 \mathrm{mg} /$ literre állítottam be. A színmustot 12 órán át ülepítetem, majd zselatinnal derítettem, tápsót és SIHA-7 fajélesztőt tettem hozzá.

\section{Mustderítési}

A zselatinos derítéshez Unikén Zselatint használtam $10 \mathrm{~g} / \mathrm{hl}$ dózisban. A zselatint először 10-szeres mennyiségú hideg vízben fél óráig duzzasztottam, majd $45-50{ }^{\circ} \mathrm{C}$-os meleg vízben oldottam fel. Ez kevés mustban elegyítettem, majd a mustba homogénen belekevertem. 


\section{EREDMÉNYEK ÉS MEGVITATÁSA}

\section{A kezelt bor érzékszervi vizsgálata}

A fiatal, bentonittal derített borokat október végén mutattam be hallgatóknak, ismerősöknek, szakembereknek. $\quad A z$ egybehangzó vélemény az volt, hogy a tisztított, zselatinnal kezelt mustból eltúntek a fajtára jellemző kesernyés utóízt adó fenolvegyületek. A színmust felhasználásával eleve alacsonyabb volt a fenolanyagok mennyisége. Sokan nem kedvelik a Cserszegi fúszeres borát, mert bár az illatos és zamatanyagokban gazdag, a kóstolás végén zavaróak az említett anyagok.

\section{KÖVETKEZTETÉSEK}

Reduktív, fehér boroknál a pezsgő alapborokhoz hasonlóan alapvető követelmény, hogy a bor tiszta ízú legyen. A húzós, fanyar, kesernyés ízú fenolvegyületek jelenléte kifejezetten kedvezőtlen. A színmustokban lényegesen alacsonyabb a fenolanyagok mennyisége, mint a présmustban, ezért eleve ebből készülnek a csúcsminőségű bukéborok. A kisebb mennyiségben megjelent fenolanyagokat fehérjetartalmú derítőanyagokkal csökkenteni lehet. A kísérletben kis mennyiségű zselatinadagolás történt. A must ülepítésével szintén sok szedimentanyagot lehet a mustból kivonni. A derítőanyag hozzákeverése után került a mustba a tápsó és a nemes fajélesztő. A tápsó alkalmazását a bökser megelőzése indokolta. $A$ SIHA 7 fajélesztő tiszta ízú borokat eredményez és a must maradék nélkül kierjed.

A kezelt és kontrol bor érzékszervi bírálatakor egybehangzó volt az a vélemény, hogy az ülepített, derített színmustból erjesztett bor tisztább ízű, mint a kezeletlen bor.

\section{IRODALOMJEGYZÉK}

[1.] Csepregi P.-Zilai J. (1988): Szőlőfajtaismeret és fajtahasználat, Mezőgazdasági Kiadó, Budapest

[2.] Eperjesi I. - Kállay M. - Magyar I. (1998): Borászat, Mezőgazda Kiadó, Budapest

[3.] Ferenczi S. (1979): A borstabilitás irányai, Borgazdaság 27. (1)

[4.] Janky F. (1997): A minőségi fehérborkészítés, Kert. Élelmip. Egyetem nov. 26. 